\title{
A methodological quality assessment of systematic reviews and meta-analyses of antidepressants effect on low back pain using updated AMSTAR
}

\author{
Mohammad Hossein Panahi ${ }^{1}$, Mostafa Mohseni ${ }^{2}$, Razieh Bidhendi Yarandi ${ }^{3,4^{*}}$ a and Fahimeh Ramezani Tehrani ${ }^{4}$
}

\begin{abstract}
Background: Antidepressants are prescribed widely to manage low back pain. There are a number of systematic reviews and meta-analyses which have investigated the efficacy of the treatments, while the methodological quality of them has not been assessed yet. This study aims to evaluate the methodological quality of the systematic reviews and meta-analyses investigating the effect of antidepressants on low back pain.

Methods: A systematic search was conducted in PubMed, EMBASE, Medline, and Cochrane Library databases up to November 2018. The 16-item Assessment of Multiple Systematic Reviews (AMSTAR2) scale was used to assess the methodological quality of the studies. Systematic reviews and meta-analyses of the Antidepressants treatment effects on low back pain published in English language were included. There was no limitation on the type of Antidepressants drugs, clinical setting, and study population, while non-systematical reviews and qualitative and narrative reviews were excluded.

Results: A total of 25 systematic reviews and meta-analyses were evaluated; the studies were reported between 1992 and 2017. Obtained results from AMSTAR2 showed that 11 (44\%), 9 (36\%) and 5 (20\%) of the included studies had high, moderate and low qualities, respectively. 13(52\%) of studies assessed risk of bias and 2(20\%) of meta analyses considered publication bias. Also, 16 (64\%) of the included reviews provided a satisfactory explanation for any heterogeneity observed in the results.

Conclusions: Although the trend of publishing high quality papers in ADs effect on LBP increased recently, performing more high-quality SRs and MAs in this field with precise subgroups of the type of pains, the class of drugs and their dosages may give clear and more reliable evidence to help clinicians and policymakers.
\end{abstract}

Keywords: AMSTAR 2, Antidepressants, Low back pain, Meta-analysis, Systematic review

\section{Introduction}

Low back pain (LBP) is a major cause of disability. It was ranked first and sixth in terms of disability (YLDs) and overall burden (DALYs), respectively [1]. Pharmaceutical and non-pharmaceutical therapies are taken extensively to tackle this issue; in this way, guidelines

\footnotetext{
* Correspondence: razi_bidhendi@yahoo.com

${ }^{3}$ Department of Epidemiology and Biostatistics, School of Public Health Tehran University of Medical Sciences, Tehran, Iran

${ }^{4}$ Reproductive Endocrinology Research Center, Research Institute for Endocrine Sciences, Shahid Beheshti University of Medical Sciences, No 24, Parvane Street, Yaman Street, Velenjak, P.O.Box: 19395-4763, Tehran, Iran Full list of author information is available at the end of the article
}

provide a variety of suggested medicines and practices such as the use of nonsteroidal anti-inflammatory drugs (NSAIDs) and weak opioids in patients with nonspecific/acute LBP for short periods [2-5]. Although antidepressants (ADs) are not recommended as the firstline prescribed medicine to manage LBP, they are taken widely [2, 6-9]. There is conflicting evidence about the effect of antidepressant, different studies showed their beneficial role in pain reduction while others have opposed them due to the high risk of adverse effects such as dry mouth, dizziness, nausea, headache, and constipation and no clear evidence of efficacy [10-13]. In

(c) The Author(s). 2020 Open Access This article is distributed under the terms of the Creative Commons Attribution 4.0 International License (http://creativecommons.org/licenses/by/4.0/), which permits unrestricted use, distribution, and reproduction in any medium, provided you give appropriate credit to the original author(s) and the source, provide a link to the Creative Commons license, and indicate if changes were made. The Creative Commons Public Domain Dedication waiver (http://creativecommons.org/publicdomain/zero/1.0/) applies to the data made available in this article, unless otherwise stated. 
Table 1 Characteristics of included systematic reviews and meta analyses studies

\begin{tabular}{|c|c|c|c|c|c|}
\hline & $\begin{array}{l}\text { First author, Year, } \\
\text { Country }\end{array}$ & $\begin{array}{l}\text { Type of pain/ } \\
\text { Outcome }\end{array}$ & $\begin{array}{l}\text { Number/ Types of } \\
\text { study included }\end{array}$ & Types of treatment & $\begin{array}{l}\text { Results in terms of pain reduction/ } \\
\text { Side effects }\end{array}$ \\
\hline \multirow[t]{2}{*}{1} & $\begin{array}{l}\text { Riediger C, } 2017 \text { [12], } \\
\text { Germany }\end{array}$ & CLBP/ Adverse events & $\begin{array}{l}\text { Total:23, LBP:5/ } \\
\text { RCTs }\end{array}$ & $\begin{array}{l}\text { TCAs: Amitriptyline, Desipramine, } \\
\text { Nortriptyline, SNRIs: Venlafaxine, } \\
\text { Milnacipran, Duloxetine, TeCAs: } \\
\text { Mirtazapine, SSRIs: Fluoxetine }\end{array}$ & $\begin{array}{l}\text { Higher risk for adverse effects } \\
\text { compared to placebo, except } \\
\text { nortriptyline. }\end{array}$ \\
\hline & $\begin{array}{l}\text { Onghena P, } 1992 \text { [32], } \\
\text { Belgium }\end{array}$ & CLBP/ Pain & $\begin{array}{l}\text { Total:39, LBP: } 5 \\
\text { /RCTs }\end{array}$ & $\begin{array}{l}\text { TCAs: Imipramine, Doxepin, } \\
\text { Amitriptyline }\end{array}$ & Effective results in pain relief \\
\hline 2 & $\begin{array}{l}\text { Chung JWY, } 2013 \text { [18], } \\
\text { China }\end{array}$ & $\begin{array}{l}\text { CNLBP/ Pain, } \\
\text { Global Improvement, } \\
\text { Adverse events }\end{array}$ & $\begin{array}{l}\text { Total:25, ADs:4/ } \\
\text { RCTs }\end{array}$ & No specific subgroups & $\begin{array}{l}\text { Statistically significant treatment } \\
\text { effects in pain relief and side effects }\end{array}$ \\
\hline 3 & $\begin{array}{l}\text { Pinto RZ, } 2012 \text { [33], } \\
\text { Australia }\end{array}$ & $\begin{array}{l}\text { LBP, Sciatica/ Pain, } \\
\text { Function }\end{array}$ & $\begin{array}{l}\text { Total:23, ADs: 1/ } \\
\text { RCT }\end{array}$ & TCAs: Nortriptyline & $\begin{array}{l}\text { No significant results in pain relief } \\
\text { Data were insufficient }\end{array}$ \\
\hline 4 & $\begin{array}{l}\text { Urquhart DM, } 2010 \\
\text { [34], Australia }\end{array}$ & $\begin{array}{l}\text { NLBP/Pain, Function, } \\
\text { Depression }\end{array}$ & $10 \mathrm{RCTs}$ & $\begin{array}{l}\text { TCAs } \\
\text { SSRIS }\end{array}$ & No clear evidence of effectiveness \\
\hline 5 & $\begin{array}{l}\text { Machado LAC, } 2009 \\
\text { [35], Australia }\end{array}$ & CNLBP/ Pain & $\begin{array}{l}\text { Total:74, } A D_{s}: \\
\text { 4/ RCTs }\end{array}$ & No specific subgroups & Small analgesic effect \\
\hline 6 & $\begin{array}{l}\text { Salerno SM, } 2002 \\
\text { [36], USA }\end{array}$ & CLBP/ Pain, Function & 9 RCTs & $\begin{array}{l}\text { TCAs: Nortriptyline, Imipramine, } \\
\text { Amitriptyline, TeCAs: Maprotiline, } \\
\text { SSRIs: Paroxetine, SNRIs: } \\
\text { Duloxetine, Others: Trazodone }\end{array}$ & Effective results in pain relief \\
\hline 8 & $\begin{array}{l}\text { Chou R, } 2017[11] \\
\text { USA }\end{array}$ & $\begin{array}{l}\text { CLBP/ Pain, Function, } \\
\text { Depression }\end{array}$ & $\begin{array}{l}\text { Total:79, ADs: 16/ } \\
\text { 1SR+6RCTs }\end{array}$ & $\begin{array}{l}\text { TCAs } \\
\text { SSRIs } \\
\text { SNRIs: Duloxetine }\end{array}$ & $\begin{array}{l}\text { SNRIs: Effective on pain reduction } \\
\text { TCAs and SSRIs: No significant results }\end{array}$ \\
\hline 9 & $\begin{array}{l}\text { Van Den Driest JJ, } \\
2017 \text { [17], The } \\
\text { Netherlands }\end{array}$ & $\begin{array}{l}\text { CLBP/Pain, Function, } \\
\text { Adverse events }\end{array}$ & Total:7/ LBP: 4 & TCAs: Amitriptyline vs. Pregabalin & $\begin{array}{l}\text { Effective results in pain relief } \\
\text { Similar side effect with comparator }\end{array}$ \\
\hline 10 & $\begin{array}{l}\text { National Guideline } \\
\text { Centre (UK), } 2016 \\
\text { [2],UK }\end{array}$ & $\begin{array}{l}\text { LBP, Sciatica/ Pain, } \\
\text { Function, Adverse } \\
\text { events }\end{array}$ & $\begin{array}{l}\text { Total:55, ADs: } \\
\text { 10/RCTs }\end{array}$ & TCAs, SSRIS, SNRIS & $\begin{array}{l}\text { No clear evidence of effectiveness. } \\
\text { SSRIs, SNRIs significant adverse event }\end{array}$ \\
\hline 11 & $\begin{array}{l}\text { Chou R, } 2016 \text { [37], } \\
\text { USA }\end{array}$ & CLBP/ Pain, Function & $\begin{array}{l}\text { Total:153, ADs: } \\
4 \text { /1SR + } 3 \text { RCTs }\end{array}$ & TCAs, SSRIs, SNRIs: Duloxetine & $\begin{array}{l}\text { SSRIs and TCAS: No effect on pain } \\
\text { reduction } \\
\text { SNRIs: small effect on pain reduction }\end{array}$ \\
\hline 12 & $\begin{array}{l}\text { Mercier A,2013 [38], } \\
\text { France }\end{array}$ & NLBP, Sciatica/ Pain & $\begin{array}{l}\text { Total:78, LBP:3/ } \\
\text { RCTs }\end{array}$ & No specific subgroups & $\begin{array}{l}\text { No AD treatments recommended. } \\
\text { Only in the event of associated } \\
\text { Depression }\end{array}$ \\
\hline 13 & $\begin{array}{l}\text { RomanoCL,2012 [39], } \\
\text { Italy }\end{array}$ & $\begin{array}{l}\text { CLBP/ Pain, Function, } \\
\text { Depression }\end{array}$ & $\begin{array}{l}\text { Total: 6, ADs: } \\
\text { 1/ RCT }\end{array}$ & TCAs: Nortriptyline & $\begin{array}{l}\text { No significant results for } \\
\text { monotherapy }\end{array}$ \\
\hline 14 & $\begin{array}{l}\text { Morlion B, } 2011 \text { [40], } \\
\text { Belgium }\end{array}$ & LBP/ pain, Function & Ads:10 & No specific subgroups & $\begin{array}{l}\text { Small benefits for Ads. } \\
\text { TCAs are recommended }\end{array}$ \\
\hline 15 & $\begin{array}{l}\text { Kuijpers T, } 2011 \text { [16], } \\
\text { The Netherlands }\end{array}$ & $\begin{array}{l}\text { CNLBP/ Pain, Function, } \\
\text { Adverse events }\end{array}$ & $\begin{array}{l}\text { Total: } 17, \mathrm{AD}_{\mathrm{s}}: \\
5 \text { / SR and } \mathrm{MA}\end{array}$ & No specific subgroups & $\begin{array}{l}\text { No clear evidence of effectiveness } \\
\text { and side effects }\end{array}$ \\
\hline 16 & $\begin{array}{l}\text { Savigny P,2009 [41], } \\
\text { UK }\end{array}$ & $\begin{array}{l}\text { NLBP/ Pain, Function, } \\
\text { Depression }\end{array}$ & $1 \mathrm{SR}+10 \mathrm{RCTS}$ & TCAs, SSRIS, SNRIS & No clear evidence of effectiveness \\
\hline 17 & $\begin{array}{l}\text { Chou R, } 2007 \text { [15], } \\
\text { USA }\end{array}$ & $\begin{array}{l}\text { CLBP/ Pain, Function, } \\
\text { Adverse events }\end{array}$ & $3 S R$ & $\begin{array}{l}\text { TCAs: Nortriptyline, Imipramine, } \\
\text { Amitriptyline, Desipramine } \\
\text { SSRIs: Paroxetine } \\
\text { SNRIs: Duloxetine, Venlafaxine } \\
\text { Others: Maprotiline, Trazodone }\end{array}$ & $\begin{array}{l}\text { Only TCAs have } \\
\text { been shown effective. } \\
\text { No evidence on SNRIs, SSRIs. } \\
\text { Insufficient evidence for Others. } \\
\text { Significantly higher risk for any } \\
\text { adverse event. }\end{array}$ \\
\hline 18 & $\begin{array}{l}\text { Staiger THO, } 2003[42], \\
\text { USA }\end{array}$ & CLBP/ Pain, Function & 7 RCTs & $\begin{array}{l}\text { TCAs: Nortriptyline, Imipramine, } \\
\text { Amitriptyline, SSRIs: Paroxetine, } \\
\text { TeCAs: Maprotiline, Others: } \\
\text { Trazodone }\end{array}$ & $\begin{array}{l}\text { TCAs and TeCAs: moderate } \\
\text { symptom reductions } \\
\text { SSRIs: Not beneficial }\end{array}$ \\
\hline 19 & $\begin{array}{l}\text { White AP,2011 [43], } \\
\text { USA }\end{array}$ & $\begin{array}{l}\text { CLBP/ Pain, Function, } \\
\text { Adverse events }\end{array}$ & Total: 6 & $\begin{array}{l}\text { TCAs: Desipramine, Imipramine } \\
\text { SSRIs: Paroxetine, Fluoxetine }\end{array}$ & $\begin{array}{l}\text { No effective than placebo. } \\
\text { No differences between differing } \\
\text { types of ADs. }\end{array}$ \\
\hline 20 & Cawston H,2013 [44], & CLBP/Pain & 4 RCTs+ MAs & SNRIs: Duloxetine & No difference in efficacy between \\
\hline
\end{tabular}


Table 1 Characteristics of included systematic reviews and meta analyses studies (Continued)

\begin{tabular}{|c|c|c|c|c|c|}
\hline & $\begin{array}{l}\text { First author, Year, } \\
\text { Country }\end{array}$ & $\begin{array}{l}\text { Type of pain/ } \\
\text { Outcome }\end{array}$ & $\begin{array}{l}\text { Number/ Types of } \\
\text { study included }\end{array}$ & Types of treatment & $\begin{array}{l}\text { Results in terms of pain reduction/ } \\
\text { Side effects }\end{array}$ \\
\hline & France & & & & $\begin{array}{l}\text { duloxetine and other oral } \\
\text { pharmacological therapies. }\end{array}$ \\
\hline 21 & $\begin{array}{l}\text { Qaseem A, } 2017 \text { [45], } \\
\text { USA }\end{array}$ & CLBP/ Pain & 9 RCTs & $\begin{array}{l}\text { TCAs } \\
\text { SSRIs } \\
\text { SNRIs: Duloxetine }\end{array}$ & $\begin{array}{l}\text { No difference between SSRIs and } \\
\text { TCAs. } \\
\text { Duloxetine had small effect }\end{array}$ \\
\hline 22 & $\begin{array}{l}\text { Perrot S, } 2006[46] \\
\text { France }\end{array}$ & CLBP/ Pain & $\begin{array}{l}\text { Total:99 } \\
4 \text { on CLBP }\end{array}$ & $\begin{array}{l}\text { TCAs: Nortriptyline, Imipramine, } \\
\text { Amitriptyline, TeCAs: Maprotiline } \\
\text { SSRIs: Paroxetine }\end{array}$ & $\begin{array}{l}\text { TCAs and TeCAs: Moderate symptom } \\
\text { reductions } \\
\text { SSRIs: Not Beneficial }\end{array}$ \\
\hline 23 & $\begin{array}{l}\text { Perrot S, } 2008[47] \\
\text { France }\end{array}$ & CLBP/ Pain & $\begin{array}{l}\text { Total:52 } \\
11 \text { on CLBP }\end{array}$ & $\begin{array}{l}\text { TCAs: Nortriptyline, Imipramine, } \\
\text { Clomipramine, Amitriptyline } \\
\text { SSRIs: Paroxetine, Bupropion } \\
\text { TeCAs: Maprotiline } \\
\text { Others: Trazodone }\end{array}$ & $\begin{array}{l}\text { SSRIs seem to be less effective than } \\
\text { TCAs }\end{array}$ \\
\hline 24 & $\begin{array}{l}\text { Patetsos E,2016 [48], } \\
\text { Denmark }\end{array}$ & CLBP/ Pain & $\begin{array}{l}\text { Total:36 } \\
2 \text { on CLBP }\end{array}$ & SSRIs: Paroxetine & No significant results \\
\hline 25 & $\begin{array}{l}\text { Schnitzer Th J,2004 } \\
\text { [49], USA }\end{array}$ & CLBP/ Pain & $\begin{array}{l}\text { Total: } 55 \text {, ADs: } \\
7 \text { RCTs }\end{array}$ & No specific subgroups & $\begin{array}{l}\text { Evidence exists regarding the } \\
\text { efficacy of antidepressants }\end{array}$ \\
\hline
\end{tabular}

Abbreviations: CLBP Chronic Low Back Pain, NLBP Non-specific Low Back Pain, CNLBP Chronic Non-specific Low Back Pain, MA Meta-Analysis, $R$ Review, NR Narrative Review, SR Systematic Review, CSR Comprehensive Systematic Review, ADs Antidepressants, TCAs Tricyclic Antidepressants, TeCA Tetracyclic Antidepressant, SSR/s Selective Serotonin Reuptake Inhibitor, SNRIs Serotonin-Norepinephrine Reuptake Inhibitors, SARI Serotonin Antagonist and Reuptake Inhibitor

addition, some systematic reviews (SRs) and meta-analyses (MAs) which summarized the results of the available evidence, provided heterogeneous results which make it difficult to decision regarding the efficacy of ADs [14-18].

An SR is a type of literature review which critically evaluates research studies. It can summarize results obtained from a plethora of studies helping researchers and clinicians to keep up with the new findings. MA is also a statistical approach to summarize the evidence extracted from secondary data obtained from the SR of studies in a specific subject. SRs and MAs provide a reference source for aiding experts in decision making. Despite their rapid growth and profound influence in health science, discrepancies of the results in studies on the same subject has made them unreliable in decision making. One reason is the matter of methodological quality of the reviews [19-21]. In this respect, evaluating the reliability and methodological quality of the studies is of great importance. There are some technical and methodological approaches to enrich SRs and MAs in order to reach valid results [22-26]. For this purpose, the Assessment of Multiple Systematic Reviews (AMSTAR) scale provides an appraisal tool for measuring the methodological quality of SRs $[27,28]$. The purpose of this study was to assess the methodological quality of SRs and MAs of the role of ADs in treating LBP using the updated version of AMSTAR.

\section{Materials and methods}

\section{Data sources and study selection}

We searched for all SRs and MAs up to November 2018 using the PubMed, EMBASE, Medline, and Cochrane
Library databases. Our search strategy followed the recommendations of the Cochrane Back Review Group [22-24]. Combinations of the following keywords were used in the search: "low back pain" AND "chronic low back pain" AND "non-specific low back pain" AND "sciatica" AND "leg pain" AND "antidepressant" AND ("TCA" OR "tricyclic antidepressants") AND ("SSRI" OR "selective serotonin reuptake inhibitors") AND ("SNRI" OR "serotonin and norepinephrine reuptake inhibitors") AND ("TeCA" OR "tetracyclic antidepressants") AND "meta-analysis" AND "systematic review". The text words and $\mathrm{MeSH}$ terms were entered depending on the databases characteristics. The reference lists from retrieved articles were also screened for additional applicable studies.

\section{Inclusion and exclusion criteria}

We included SRs and MAs of the ADs treatment effects on LBP published in English language. We also included all types of low back pain such as Chronic Low Back Pain (CLBP), Non-specific Low Back Pain (NLBP), Chronic Non-specific Low Back Pain (CNLBP) and sciatica, regardless of the cause of pain such as cancer, fracture, inflammatory disease, etc. There was no limitation on the type of ADs drugs, clinical setting, and study population, while non-systematical reviews and qualitative and narrative reviews were excluded.

\section{Study selection and data extraction}

Screening of titles and abstracts of the retrieved studies for inclusion was conducted by two independent reviewers (RBY and MHP). The full texts of the eligible 
reviews were extracted and evaluated to determine whether they met the inclusion criteria by RBY and MHP. Any disagreements were resolved by consensus through discussion and the third person (FRT). For each study, the following information was extracted: authors, year of publication, study design, type of study and intervention, characteristics of study population, outcome measurement and summary of obtained 50 results. PRISMA flow diagram [29] was used to guide the process of inclusion and exclusion of studies.
Assessment of methodological quality of included studies Quality assessment was performed independently by two authors (RBY and MHP). Any discrepancies were resolved by discussion, and a blinded third reviewer was consulted if necessary. We used the updated Assessment of Multiple Systematic Reviews (AMSTAR2) appraisal tool to evaluate the methodological quality of eligible SRs and MAs [28]. It has some advantages compared to its previous version, such as the inclusion of non-randomized studies in SRs, and a different scoring system which helps reduce bias produced by quality scores obtained traditionally by summing up

Table 2 Methodological quality of systematic reviews or meta-analyses using AMSTAR2

\begin{tabular}{|c|c|c|c|c|c|c|c|c|c|c|c|c|c|c|c|c|c|c|c|}
\hline \multirow{3}{*}{$\overline{1}$} & \multirow{3}{*}{$\begin{array}{l}\text { First author } \\
\text { Onghena P }\end{array}$} & \multirow{3}{*}{$\begin{array}{l}\text { Type of } \\
\text { study/ } \\
\text { Publication } \\
\text { year } \\
\text { SR/MA } 1992\end{array}$} & \multicolumn{16}{|c|}{ AMSTAR2 Quality Items } & \multirow{3}{*}{$\begin{array}{l}\text { AMSTAR2 } \\
\text { Classification } \\
\text { Low }\end{array}$} \\
\hline & & & \multirow{2}{*}{$\begin{array}{l}1 \\
Y\end{array}$} & \multirow{2}{*}{$\begin{array}{l}2 \\
N\end{array}$} & \multirow{2}{*}{$\begin{array}{l}3 \\
N\end{array}$} & \multirow{2}{*}{$\begin{array}{l}4 \\
Y\end{array}$} & \multirow{2}{*}{$\begin{array}{l}5 \\
N\end{array}$} & \multirow{2}{*}{$\begin{array}{l}6 \\
\mathrm{~N}\end{array}$} & \multirow{2}{*}{$\begin{array}{l}7 \\
\\
Y\end{array}$} & \multirow{2}{*}{$\begin{array}{l}8 \\
Y\end{array}$} & \multirow{2}{*}{$\begin{array}{l}9 \\
P Y\end{array}$} & \multirow{2}{*}{$\begin{array}{l}10 \\
\mathrm{~N}\end{array}$} & \multirow{2}{*}{$\begin{array}{l}11 \\
Y\end{array}$} & \multirow{2}{*}{$\begin{array}{l}12 \\
\mathrm{~N}\end{array}$} & \multirow{2}{*}{$\begin{array}{l}13 \\
\mathrm{~N}\end{array}$} & \multirow{2}{*}{$\begin{array}{l}14 \\
\mathrm{~N}\end{array}$} & \multirow{2}{*}{$\begin{array}{l}15 \\
N\end{array}$} & \multirow{2}{*}{$\begin{array}{c}\overline{16} \\
\mathrm{~N}\end{array}$} & \\
\hline & & & & & & & & & & & & & & & & & & & \\
\hline 2 & Salerno SM & SR/MA 2002 & $N$ & $\mathrm{~N}$ & N & Y & Y & Y & Y & Y & PY & $\mathrm{N}$ & Y & PY & PY & $\mathrm{N}$ & Y & $\mathrm{N}$ & Moderate \\
\hline 3 & Machado LAC & SR/MA 2009 & Y & $\mathrm{N}$ & Y & Y & Y & Y & Y & Y & PY & $\mathrm{N}$ & Y & PY & PY & $N$ & $\mathrm{~N}$ & Y & Moderate \\
\hline 4 & Urquhart DM & SR/MA 2010 & Y & Y & Y & Y & Y & Y & Y & Y & Y & Y & Y & Y & Y & Y & $Y$ & Y & High \\
\hline 5 & White AP & SR/MA 2011 & Y & $\mathrm{N}$ & Y & Y & Y & Y & Y & Y & Y & Y & $N$ & Y & Y & Y & $\mathrm{N}$ & $\mathrm{N}$ & Moderate \\
\hline 6 & Pinto RZ & SR/MA 2012 & Y & $\mathrm{N}$ & Y & Y & $Y$ & Y & $Y$ & Y & Y & Y & Y & $Y$ & Y & Y & $\mathrm{N}$ & $Y$ & High \\
\hline 7 & Cawston H & SR/MA 2013 & Y & $\mathrm{N}$ & Y & $Y$ & Y & Y & Y & Y & Y & Y & Y & $Y$ & Y & Y & $\mathrm{N}$ & Y & High \\
\hline 8 & Chung JWY & SR/MA 2013 & Y & $\mathrm{N}$ & Y & Y & $\mathrm{N}$ & Y & Y & Y & Y & Y & Y & $\mathrm{N}$ & $N$ & Y & $\mathrm{N}$ & Y & Moderate \\
\hline 9 & Riediger C & SR/MA 2017 & Y & $\mathrm{N}$ & Y & Y & $\mathrm{N}$ & $\mathrm{N}$ & Y & Y & Y & Y & Y & Y & Y & Y & $N$ & Y & Moderate \\
\hline 10 & Qaseem A & SR/MA 2017 & Y & $\mathrm{N}$ & Y & Y & Y & Y & Y & Y & Y & Y & Y & Y & Y & Y & $\mathrm{N}$ & Y & High \\
\hline 11 & Staiger THO & SR/2003 & Y & $\mathrm{N}$ & Y & Y & Y & Y & Y & Y & PY & Y & NM & NM & Y & $N$ & NM & $\mathrm{N}$ & Moderate \\
\hline 12 & Schnitzer Th J & SR 2004 & Y & $\mathrm{N}$ & Y & Y & Y & Y & Y & Y & PY & Y & NM & NM & PY & Y & NM & Y & Moderate \\
\hline 13 & Perrot S & SR 2006 & Y & $\mathrm{N}$ & $\mathrm{N}$ & Y & Y & Y & $\mathrm{N}$ & $N$ & PY & $N$ & NM & NM & PY & $N$ & NM & $\mathrm{N}$ & Low \\
\hline 14 & Chou R & SR/2007 & Y & $\mathrm{N}$ & $Y$ & Y & Y & Y & Y & Y & PY & Y & NM & NM & PY & Y & NM & $Y$ & Moderate \\
\hline 15 & Perrot S & SR 2008 & Y & $\mathrm{N}$ & $Y$ & $Y$ & Y & Y & $\mathrm{N}$ & Y & PY & $N$ & NM & NM & PY & $\mathrm{N}$ & NM & $Y$ & Moderate \\
\hline 16 & Savigny & SR/2009 & Y & $\mathrm{N}$ & $Y$ & $Y$ & Y & Y & Y & $\mathrm{N}$ & Y & Y & NM & NM & Y & Y & NM & Y & High \\
\hline 17 & Morlion B & SR/2011 & $N$ & $\mathrm{~N}$ & Y & $\mathrm{N}$ & $N$ & $\mathrm{~N}$ & Y & Y & $N$ & Y & NM & NM & $\mathrm{N}$ & $\mathrm{N}$ & NM & Y & Low \\
\hline 18 & Kuijpers T & SR/2011 & Y & $\mathrm{N}$ & Y & $Y$ & $Y$ & $Y$ & Y & Y & Y & Y & NM & NM & Y & $Y$ & NM & $Y$ & High \\
\hline 19 & Romano CL & SR/2012 & Y & $\mathrm{N}$ & $N$ & Y & Y & Y & Y & Y & $N$ & Y & NM & NM & $\mathrm{N}$ & $\mathrm{N}$ & NM & Y & Low \\
\hline 20 & Mercier A & SR/2013 & Y & $\mathrm{N}$ & $\mathrm{N}$ & $Y$ & Y & Y & Y & $\mathrm{N}$ & $N$ & Y & NM & NM & $N$ & $N$ & NM & Y & Low \\
\hline 21 & Patetsos E & SR 2016 & Y & Y & Y & Y & Y & Y & Y & Y & Y & Y & NM & NM & Y & Y & NM & Y & High \\
\hline 22 & Chou R & $\mathrm{SR} / 2016$ & Y & Y & Y & Y & Y & Y & Y & Y & Y & Y & NM & NM & Y & Y & NM & Y & High \\
\hline 23 & National Guideline & SR/2016 & Y & Y & Y & Y & Y & Y & Y & Y & Y & Y & NM & NM & Y & Y & NM & Y & High \\
\hline 24 & Chou R & SR/2017 & Y & Y & Y & Y & Y & Y & Y & Y & Y & Y & NM & NM & Y & Y & NM & Y & High \\
\hline 25 & Van Den Driest Jנ & SR/2017 & Y & $\mathrm{N}$ & Y & Y & Y & Y & Y & Y & Y & Y & NM & NM & Y & Y & NM & Y & High \\
\hline
\end{tabular}

$Y$ Yes, PY Partial Yes, N No, NM No Meta-analysis AMSTAR2 Classifications:

High: No or one non-critical weakness: the systematic review provides an accurate and comprehensive summary of the results of the available studies that address the question of interest

Moderate: More than one non-critical weakness: the systematic review has more than one weakness but no critical flaws. It may provide an accurate summary of the results of the available studies that were included in the review

Low: One critical flaw with or without non-critical weaknesses: the review has a critical flaw and may not provide an accurate and comprehensive summary of the available studies that address the question of interest

Critically low: More than one critical flaw with or without non-critical weaknesses: the review has more than one critical flaw and should not be relied on to provide an accurate and comprehensive summary of the available studies 
scores and getting an overall score [30]. AMSTAR2 contains 16 items; i.e., four domains have been added to this new version of AMSATR. Two of these were adopted directly from the ROBINS-I tool, namely, elaboration of the PICO and the way in which risk of bias was handled during evidence synthesis. Another one was the discussion of possible causes and significance of heterogeneity. The last new domain was the justification of selection of study designs to deal with non-randomized designs. The domain-specific questions in AMSTAR 2 are framed so that a "Yes" answer denotes a positive result. "Not Applicable" and "Cannot Answer" options in the original AMSTAR instrument were removed and "Partial Yes" responses have been provided where it is worthwhile to identify partial adherence to the standard. Moreover, the AMSTAR tool has a good agreement, reliability, construct validity, and feasibility to assess the quality of systematic reviews [31].

\section{Data analysis}

Characteristics of the studies are reported in Table 1. In addition, Tables 2 and 3 show the results of AMSTAR2 domain ("Yes", "Partial Yes", "No") of each included study. Moreover, the secular trend of the number and quality of included reviews was illustrated as well.

\section{Results \\ Study identification}

Through the initial search, we extracted 3700 potentially relevant articles by searching electronic databases and other resources. After skimming the titles and abstracts and identifying duplications, 3646 articles were excluded. The full texts of the remaining 54 articles were read carefully in their entirety. Twenty-five articles were eligible for the inclusion; 29 Narrative/reviews were excluded from the assessment. All included studies were

Table 3 Methodological quality of the included meta-analyses and systematic reviews

\begin{tabular}{|c|c|c|c|c|}
\hline Items & & $\mathrm{Y}, \mathrm{n}(\%)$ & PY, n (\%) & $\mathrm{N}, \mathrm{n}(\%)$ \\
\hline 1 & $\begin{array}{l}\text { Did the research questions and inclusion criteria for the review include } \\
\text { the components of PICO (population, intervention, control group and } \\
\text { outcome)? }\end{array}$ & $23(92)$ & $0(0)$ & $2(8)$ \\
\hline 2 & $\begin{array}{l}\text { Did the report of the review contain an explicit statement that the review } \\
\text { methods were established prior to conduct of the review and did the } \\
\text { report justify any significant deviations from the protocol? }\end{array}$ & $4(16)$ & $0(0)$ & $21(84)$ \\
\hline 3 & $\begin{array}{l}\text { Did the review authors explain their selection of the study designs for } \\
\text { inclusion in the review? }\end{array}$ & $20(80)$ & $0(0)$ & $5(20)$ \\
\hline 4 & $\begin{array}{l}\text { Did the review authors use a comprehensive literature search } \\
\text { strategy? }\end{array}$ & $24(96)$ & $0(0)$ & $1(4)$ \\
\hline 5 & Did the review authors perform study selection in duplicate? & $21(84)$ & $0(0)$ & $4(16)$ \\
\hline 6 & Did the review authors perform data extraction in duplicate? & $22(88)$ & $0(0)$ & $3(12)$ \\
\hline 7 & $\begin{array}{l}\text { Did the review authors provide a list of excluded studies and justify the } \\
\text { exclusions? }\end{array}$ & $22(88)$ & $0(0)$ & $3(12)$ \\
\hline 8 & $\begin{array}{l}\text { Did the review authors describe the included studies in adequate } \\
\text { detail? }\end{array}$ & $22(88)$ & $0(0)$ & $3(12)$ \\
\hline 9 & $\begin{array}{l}\text { Did the review authors use a satisfactory technique for assessing the risk } \\
\text { of bias (RoB) in individual studies that were included in the review? }\end{array}$ & $13(52)$ & $8(32)$ & $4(16)$ \\
\hline 10 & $\begin{array}{l}\text { Did the review authors report on the sources of funding for the studies } \\
\text { included in the review? }\end{array}$ & $20(80)$ & $0(0)$ & $5(20)$ \\
\hline 11 & $\begin{array}{l}\text { If meta-analysis (MA) was justified did the review authors use appropriate } \\
\text { methods for statistical combination of results? }\end{array}$ & $9(90)$ & $0(0)$ & $1(10)$ \\
\hline 12 & $\begin{array}{l}\text { If meta-analysis was performed did the review authors assess the } \\
\text { potential impact of RoB in individual studies on the results of } \\
\text { the meta-analysis or other evidence synthesis? }\end{array}$ & $5(50)$ & $2(20)$ & $3(30)$ \\
\hline 13 & $\begin{array}{l}\text { Did the review authors account for RoB in individual studies when } \\
\text { interpreting/ discussing the results of the review? }\end{array}$ & $14(56)$ & $6(24)$ & $5(20)$ \\
\hline 14 & $\begin{array}{l}\text { Did the review authors provide a satisfactory explanation for, and } \\
\text { discussion of, any heterogeneity observed in the results of the review? }\end{array}$ & $16(64)$ & $0(0)$ & $9(36)$ \\
\hline 15 & $\begin{array}{l}\text { If they performed quantitative synthesis did the review authors carry out } \\
\text { an adequate investigation of publication bias (small study bias) and } \\
\text { discuss its likely impact on the results of the review? }\end{array}$ & $2(20)$ & $0(0)$ & $8(80)$ \\
\hline 16 & $\begin{array}{l}\text { Did the review authors report any potential sources of conflict of } \\
\text { interest, including any funding they received for conducting the review? }\end{array}$ & $20(80)$ & $0(0)$ & $5(20)$ \\
\hline
\end{tabular}

Y Yes, PY Partial Yes, $N$ No, NM No meta-analysis conducted 
SRs and MAs on the role of ADs in LBP. The PRISMA flowchart guided the selection process of extracted literature (Fig. 1).

\section{Characteristics of included SRs}

Characteristics of the 25 SRs and MAs are presented in Table 1. Studies were reported between 1992 and 2017. The number of studies included in MAs ranged from 4 to 10 intervention studies on ADs. Studies included were performed on relatively homogeneous patients or populations which suffer from chronic low back pain (CLBP), nonspecific low back pain (NLBP), chronic non-specific low back pain (CNLBP) and sciatica. Moreover, multiple AD drug categories with different dosages were considered as intervention. Six out of 25 included studies had no specific subgroups of drug intervention; others consisted of selective serotonin reuptake inhibitors (SSRIs), serotonin and norepinephrine reuptake inhibitors (SNRIs), tricyclic antidepressants (TCAs), tetracyclic antidepressant (TeCA), selective serotonin reuptake inhibitors (SSRIs), and serotonin-norepinephrine reuptake inhibitors (SNRIs). Regarding study design, most studies included in MAs or SRs were randomized controlled trials. In addition, we reported the results of the AMSTAR quality assessment of each study.

\section{Assessment of methodological quality of included SRs}

The assessments of the methodological quality are given in Tables 2 and 3. Out of 25 included studies, 11, 9 and 5 studies were classified as high $[2,14,16,17,33,34,37$, $41,44,45,48]$ moderate $[12,35,36,42,43,47,49]$ and low $[32,38-40,46]$ quality, respectively.

Table 3 shows the results of the methodological quality assessment according to each item. Items 1: "Did the research questions and inclusion criteria for the review include the components of PICO (population, intervention, control group and outcome)?", 3: "Did the review authors explain their selection of the study designs for inclusion in the review?", 8: "Did the review authors describe the included studies in adequate detail?", 10: "If meta-analysis (MA) was justified did the review authors use appropriate methods for statistical combination of results?", 11: "If meta-analysis (MA) was justified did the review authors use appropriate methods for statistical combination of results?" and 16: "Did the review authors report any potential sources of conflict of interest, including any funding they received for conducting the

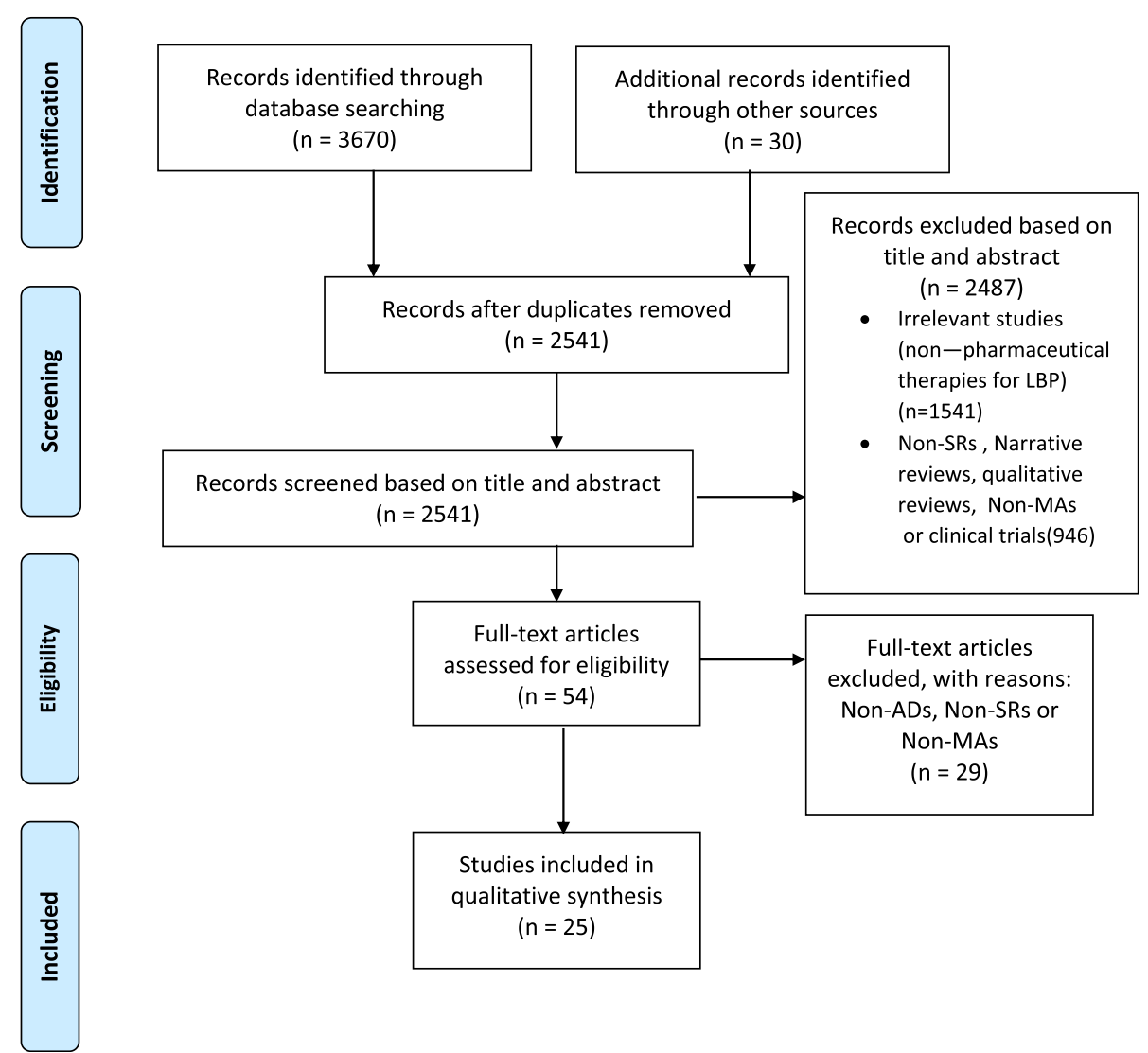

Fig. 1 PRISMA Flow Diagram of the Review Search and Identification 
review?" were the most common AMSTAR items in which the studies scored highest, while they lost points in 2: "Did the report of the review contain an explicit statement that the review methods were established prior to conduct of the review and did the report justify any significant deviations from the protocol?" and 15: "If they performed quantitative synthesis did the review authors carry out an adequate investigation of publication bias (small study bias) and discuss its likely impact on the results of the review?". For items 9, 12, 13 and 14 which were related to the issue of Risk of Bias (RoB) and heterogeneity, they got an average score. 13 (52\%) of the studies used a satisfactory technique for assessing the RoB; the Cochrane Collaboration's tool was the most common tool applied. 5 (50\%) of MAs assessed the potential impact of RoB in individual studies on the results of the meta-analysis or other evidence synthesis. 14 (56\%) of the review studies accounted for RoB in individual studies when interpreting the results of the review and $16(64 \%)$ of them provided a satisfactory explanation for, and discussion of, any heterogeneity observed in the results of the review. Only 2 (20\%) of the meta-analyses out of 10 carried out an adequate investigation of publication bias (small study bias) and discussed its likely impact on the results of the review. Trend analysis showed that since 2016 an increasing trend was observed with regard to the number of publications in this topic with high quality (Fig. 2).

\section{Discussion}

Methodological quality assessment

To the best of our knowledge, this is the first study to examine specifically the quality of SRs and MAs on the effectiveness of ADs on LBP using AMSTAR 2. In our study, 11 (44\%), 9 (36\%) and 5 (20\%) studies were classified as high, moderate, and low quality, respectively. The former version of AMSTAR assigns even weights to each item and produces an overall score while it is subjected to bias estimation. To overcome this issue, AMSTAR 2 has been designed in a way that it does not estimate an overall score. A high score may disguise critical weaknesses in specific domains, such as an inadequate literature search or a failure to assess the risk of bias (RoB). RoB is a critical section of the appraisal of any systematic reviews. It was conducted by 13 (52\%) of the studies which mostly applied the Cochrane Collaboration's tool. 8 (32\%) of the studies assessed quality instead of RoB; we mention them as well to distinguish studies which did none. Contrary to the AMSTAR which focused on the quality assessment of included studies (Item 7), AMSTAR 2 considered RoB in

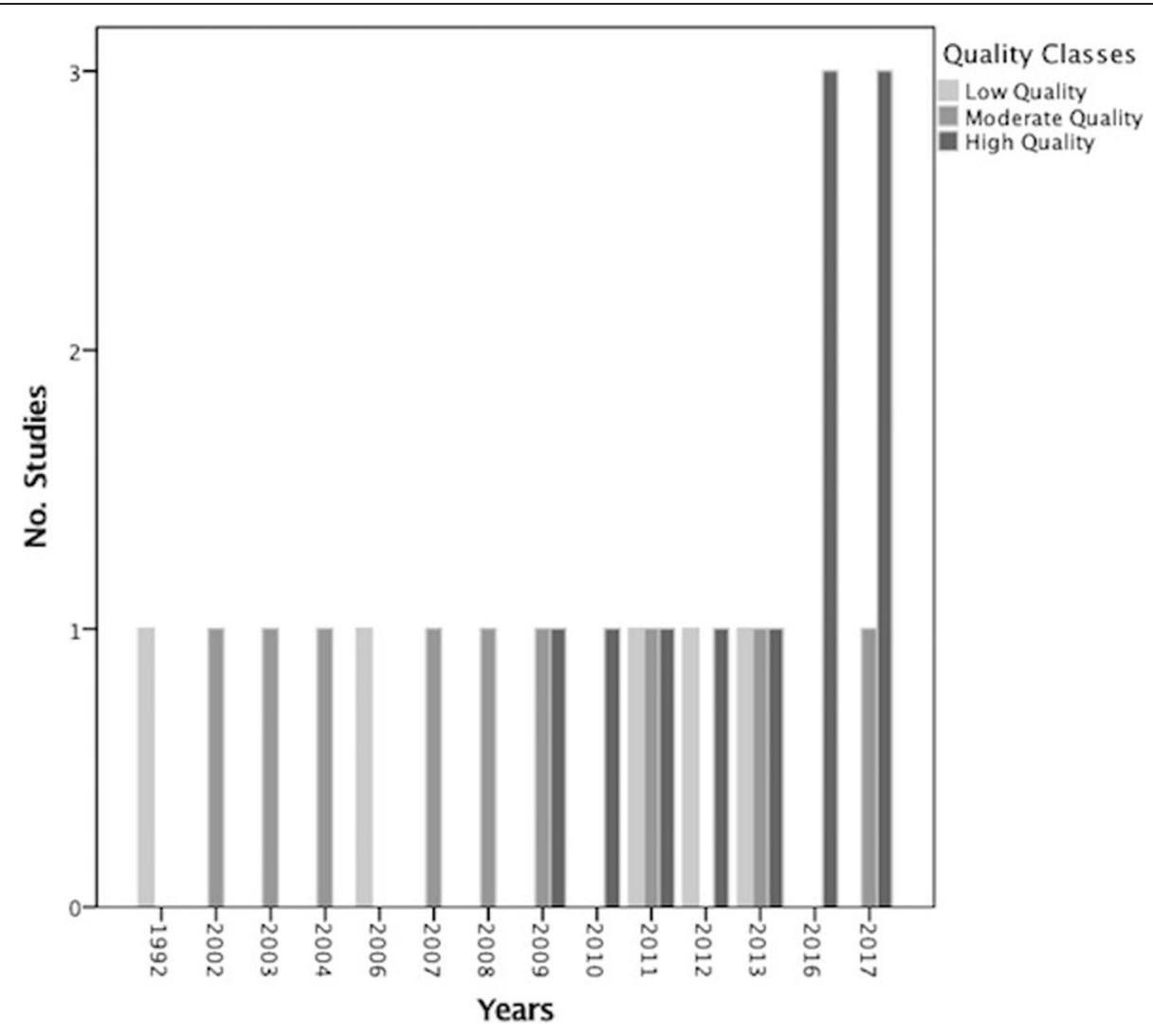

Fig. 2 The secular trend of the number and quality of included reviews 
three items $[9,12,13]$. A study may have the highest possible quality and yet have an important risk of bias. For example, in many situations, it is impractical or impossible to blind participants or study personnel to the intervention group. The Newcastle Ottawa Scale, SIGN, and the Mixed Methods Appraisal Tool as well as Cochrane instrument and ROBINS-I are the most comprehensive instruments for assessing RoB. It is important that the impact of RoB be considered in the results of the MAs, so they should assess the impact of this by meta-regression analysis, or by estimating pooled effect sizes by excluding studies at high RoB through sensitivity analysis. 16 (64\%) of the included reviews provided a satisfactory explanation for any heterogeneity observed in the results. As a matter of fact, heterogeneity in the SRs and MAs points to the variation in study outcomes between studies. Considering potential sources of heterogeneity which can be related to the domains of bias or PICO description (population, intervention, control group and outcome) is essential. Assessing heterogeneity through Chi-squared test or Isquared index and conducting appropriate methods of analysis like Fixed/Random-effect models and other methods such as meta-regression and sensitivity analysis help detect sources of heterogeneity and strengthen the results. In addition, $2(20 \%)$ of the included MAs carried out an adequate investigation of publication bias and discussed its likely impact on the results. Methods of exploring publication bias in MAs such as funnel plot, Egger and Begg's test, etc., were presented [50-53]. In addition, the secular trend of studies showed that since 2007 which was the initiation of AMSTAR more publications at moderate to high quality were published and since 2016 most of them were high-quality. It showed that authors were more aware of items which can improve the quality of their research and consequently provide more precise and reliable results.

\section{Summary of ADs effect on LBP}

Most SRs and MAs in this area, illustrated that there was no clear evidence of ADs effectiveness on LPB $[2,16,34,41,54-56]$ while others achieved contradictory results $[18,35,36,57,58]$. Some of them showed that TCAs had significant analgesic effect more than other types of Ads [15, 17, 32, 40, 42, 59-62], while there exists contradiction as well [63]. In addition, some reviews reported a lack of sufficient data for the conclusion [33, 55, 64]. Significant side effects were observed in ADs as well $[2,12,15,18]$.

\section{Strengths and limitations}

The present study is the first to comprehensively assess the methodological quality of SRs on the effect of ADs on LBP. We used the updated version of AMSTAR appraisal tools (AMSTAR 2) which has some merits over the older version. This evaluation can help experts to rely on high-quality studies when getting stuck in the dilemma of conflicting literature. A limitation of our study was that it only included reviews published in English, so publication bias could be introduced.

\section{Conclusion}

Although the trend of publishing high quality papers in ADs effect on LBP increased recently, performing more high-quality SRs and MAs in this field with precise subgroups of the type of pains, the class of drugs and their dosages may give clear and more reliable evidence to help clinicians and policymakers.

\section{Abbreviations \\ ADs: Antidepressants; AMSTAR: Assessment of Multiple Systematic Reviews; CLBP: Chronic Low Back Pain; CNLBP: Chronic Non-specific Low Back Pain; MAs: Meta-Analyses; NLBP: Non-specific Low Back Pain; PICO: Population, Intervention, Control group and Outcome; SNRIs: Serotonin and Norepinephrine Reuptake Inhibitors; SRs: Systematic Reviews; SSRIs: Selective Serotonin Reuptake Inhibitors; TCAs: Tricyclic Antidepressants; \\ TeCA: Tetracyclic Antidepressant}

\section{Acknowledgements}

The authors would like to acknowledge Dr. Amir Ghorbanpour for critical editing of English grammar and syntax of the manuscript.

\section{Authors' contributions}

MHP (Epidemiologist), MM (Neurosurgeon), FRT (MD) and RBY (Biostatistician) had significant contribution to the conception, design, acquisition, analysis and interpretation of the information. Methodological concepts were considered by RBY, MHP and prof. FRT, and medical concepts were critically interpreted by MM, FRT and MHP. All authors worked on the drafting and agreed on final approval of the version to be published. Also, agreement to be accountable for all aspects of the work in ensuring that questions related to the accuracy or integrity of any part of the work are appropriately investigated and resolved.

\section{Funding}

This research received no specific grant from any funding agency in the public, commercial, or not-for-profit sectors.

Availability of data and materials

All data generated or analyzed during the current study are included in this published article.

Ethics approval and consent to participate

Not applicable.

\section{Consent for publication}

Not applicable.

\section{Competing interests}

The authors declare that they have no competing interests.

\section{Author details}

${ }^{1}$ Department of Epidemiology, School of Public Health, Shahid Beheshti University of Medical Sciences, Tehran, Iran. ${ }^{2}$ Neurosurgery Department, Shohada Tajrish Hospital, Shahid Beheshti University of Medical Sciences, Tehran, Iran. ${ }^{3}$ Department of Epidemiology and Biostatistics, School of Public Health, Tehran University of Medical Sciences, Tehran, Iran. ${ }^{4}$ Reproductive Endocrinology Research Center, Research Institute for Endocrine Sciences, Shahid Beheshti University of Medical Sciences, No 24, Parvane Street, Yaman Street, Velenjak, P.O.Box: 19395-4763, Tehran, Iran. 
Received: 12 February 2019 Accepted: 14 January 2020

\section{Published online: 23 January 2020}

\section{References}

1. Hoy D, March L, Brooks P, Blyth F, Woolf A, Bain C, et al. The global burden of low back pain: estimates from the global burden of disease 2010 study. Ann Rheum Dis. 2014;73(6):968.

2. National GCU. Low Back pain and sciatica in over 16 s: assessment and management: National Institute for health and care excellence (UK); 2016.

3. Wong J, Cote P, Sutton D, Randhawa K, Yu H, Varatharajan S, et al. Clinical practice guidelines for the noninvasive management of low back pain: a systematic review by the Ontario protocol for traffic injury management (OPTIMa) collaboration. Eur J Pain. 2017;21 (2):201-16.

4. Chou R, Deyo R, Friedly J, Skelly A, Hashimoto R, Weimer M, et al. Nonpharmacologic therapies for low back pain: a systematic review for an American College of Physicians Clinical Practice Guideline. Ann Intern Med. 2017;166(7):493-505.

5. Oliveira CB, Maher CG, Pinto RZ, Traeger AC, Lin C-WC, Chenot J-F, et al. Clinical practice guidelines for the management of non-specific low back pain in primary care: an updated overview. Eur Spine J. 2018;27(11):2791-803.

6. Di lorio D, Henley E, Doughty A. A survey of primary care physician practice patterns and adherence to acute low back problem guidelines. Arch Fam Med. 2000;9(10):1015.

7. Fishbain D. Evidence-based data on pain relief with antidepressants. Ann Med. 2000:32(5):305-16.

8. Koes BW, van Tulder MW, Ostelo R, Kim Burton A, Waddell G. Clinical guidelines for the Management of low Back Pain in primary care: an international comparison. Spine. 2001;26(22):2504-13.

9. Orsulak PJ, Waller D. Antidepressant drugs: additional clinical uses. J Fam Pract. 1989;28:209-16.

10. Dickens C, Jayson M, Sutton C, Creed F. The relationship between pain and depression in a trial using paroxetine in sufferers of chronic low back pain. Psychosomatics. 2000;41(6):490-9.

11. Katz J, Pennella-Vaughan J, Hetzel RD, Kanazi GE, Dworkin RH. A randomized, placebo-controlled trial of bupropion sustained release in chronic low back pain. J Pain. 2005;6(10):656-61.

12. Riediger C, Schuster T, Barlinn K, Maier S, Weitz J, Siepmann T. Adverse effects of antidepressants for chronic Pain: a systematic review and Metaanalysis. Front Neurol. 2017;8:307.

13. Atkinson JH, Slater MA, Capparelli EV, Wallace MS, Zisook S, Abramson I, et al. Efficacy of noradrenergic and serotonergic antidepressants in chronic back pain: a preliminary concentration-controlled trial. J Clin Psychopharmacol. 2007;27(2):135-42.

14. Chou R, Deyo R, Friedly J, Skelly A, Weimer M, Fu R, et al. Systemic pharmacologic therapies for low back pain: a systematic review for an American College of Physicians clinical practice guideline. Ann Intern Med. 2017;166(7):480-92.

15. Chou R, Huffman LH. Medications for acute and chronic low back pain: a review of the evidence for an American pain society/American College of Physicians clinical practice guideline. Ann Intern Med. 2007;147(7):505-14.

16. Kuijpers T, van Middelkoop M, Rubinstein S, Ostelo R, Verhagen A, Koes B, et al. A systematic review on the effectiveness of pharmacological interventions for chronic non-specific low-back pain. Eur Spine J. 2011;20(1):40-50.

17. van den Driest JJ, Bierma-Zeinstra SM, Bindels PJ, Schiphof D. Amitriptyline for musculoskeletal complaints: a systematic review. Fam Pract. 2017;34(2):138-46.

18. Chung J, Zeng Y, Wong T. Drug therapy for the treatment of chronic nonspecific low back pain: systematic review and meta-analysis. Pain Physician. 2013;16(6):E685-704.

19. Moher D, Soeken K, Sampson M, Ben-Porat L, Berman B. Assessing the quality of reports of systematic reviews in pediatric complementary and alternative medicine. BMC Pediatr. 2002;2(1):3.

20. Sharif MO, Janjua-Sharif F, Ali H, Ahmed F. Systematic reviews explained: AMSTAR-how to tell the good from the bad and the ugly. Oral Health Dent Manag. 2013;12(1):9-16.

21. Cornell JE, Laine C. The science and art of deduction: complex systematic overviews. Ann Intern Med. 2008;148(10):786-8.

22. van Tulder M, Furlan A, Bombardier C, Bouter L, Group tEBotCCBR. Updated method guidelines for systematic reviews in the Cochrane collaboration Back review group. Spine. 2003;28(12):1290-9.
23. Furlan AD, Pennick V, Bombardier C, van Tulder M. 2009 updated method guidelines for systematic reviews in the Cochrane Back review group. Spine. 2009;34(18):1929-41.

24. Furlan AD, Malmivaara A, Chou R, Maher CG, Deyo RA, Schoene M, et al. 2015 updated method guideline for systematic reviews in the Cochrane Back and neck group. Spine. 2015;40(21):1660-73.

25. Higgins JPTTJ, Chandler J, Cumpston M, Li T, Page MJ, Welch VA. Cochrane Handbook for Systematic Reviews of Interventions version 6.0 Cochrane. 2nd ed; 2019. [updated July 2019: [Available from: www.handbook. cochrane.org. Accessed 10 Sept 2018]

26. Furlan AD, Pennick V, Bombardier C, van Tulder M, Group ftEBotCBR. 2009 updated method guidelines for systematic reviews in the Cochrane Back review group. Spine. 2009;34(18):1929-41.

27. Shea BJ, Grimshaw JM, Wells GA, Boers M, Andersson N, Hamel C, et al. Development of AMSTAR: a measurement tool to assess the methodological quality of systematic reviews. BMC Med Res Methodol. 2007;7(1):10.

28. Shea BJ, Reeves BC, Wells G, Thuku M, Hamel C, Moran J, et al. AMSTAR 2: a critical appraisal tool for systematic reviews that include randomised or nonrandomised studies of healthcare interventions, or both. BMJ. 2017;358:44008.

29. Moher D, Shamseer L, Clarke M, Ghersi D, Liberati A, Petticrew M, et al. Preferred reporting items for systematic review and meta-analysis protocols (PRISMA-P) 2015 statement. Syst Rev. 2015;4(1):1.

30. Greenland S, O'Rourke K. On the bias produced by quality scores in metaanalysis, and a hierarchical view of proposed solutions. Biostatistics. 2001;2(4):463-71.

31. Shea BJ, Bouter LM, Peterson J, Boers M, Andersson N, Ortiz Z, et al. External validation of a measurement tool to assess systematic reviews (AMSTAR). PloS one. 2007;2(12):e1350-e.

32. Onghena P, Van Houdenhove B. Antidepressant-induced analgesia in chronic non-malignant pain: a meta-analysis of 39 placebo-controlled studies. Pain. 1992:49(2):205-19.

33. Pinto RZ, Maher CG, Ferreira ML, Ferreira PH, Hancock M, Oliveira VC, et al. Drugs for relief of pain in patients with sciatica: systematic review and meta-analysis. BMJ. 2012;344:e497.

34. Urquhart DM, Hoving JL, Assendelft WJ, Roland M, van Tulder MW. Antidepressants for non-specific low back pain. Cochrane Database Syst Rev. 2008;(1):CD001703. https://doi.org/10.1002/14651858.CD001703.pub3.

35. Machado L, Kamper S, Herbert R, Maher C, McAuley J. Analgesic effects of treatments for non-specific low back pain: a meta-analysis of placebocontrolled randomized trials. Rheumatology. 2008;48(5):520-7.

36. Salerno SM, Browning R, Jackson JL. The effect of antidepressant treatment on chronic back pain: a meta-analysis. Arch Intern Med. 2002;162(1):19-24.

37. Chou R, Deyo R, Friedly J, Skelly A, Hashimoto R, Weimer M, et al. Noninvasive treatments for low back pain. 2016.

38. Mercier A, Auger-Aubin I, Lebeau J-P, Schuers M, Boulet P, Hermil J-L, et al. Evidence of prescription of antidepressants for non-psychiatric conditions in primary care: an analysis of guidelines and systematic reviews. BMC Fam Pract. 2013;14(1):55.

39. Romano CL, Romano D, Lacerenza M. Antineuropathic and antinociceptive drugs combination in patients with chronic low back pain: a systematic review. Pain Res Treat. 2012;2012:154781.

40. Morlion B. Pharmacotherapy of low back pain: targeting nociceptive and neuropathic pain components. Curr Med Res Opin. 2011;27(1):11-33.

41. Savigny $P$, Kuntze $S$, Watson $P$, Underwood M, Ritchie $G$, Cotterell $M$, et al. Low back pain: early management of persistent non-specific low back pain, vol. 14. London: National Collaborating Centre for Primary Care and Royal College of General Practitioners; 2009.

42. Staiger TO, Gaster B, Sullivan MD, Deyo RA. Systematic review of antidepressants in the treatment of chronic low back pain. Spine. 2003; 28(22):2540-5.

43. White AP, Arnold PM, Norvell DC, Ecker E, Fehlings MG. Pharmacologic Management of Chronic low Back Pain: synthesis of the evidence. Spine. 2011;36:S131-S43.

44. Cawston H, Davie A, Paget M-A, Skljarevski V, Happich M. Efficacy of duloxetine versus alternative oral therapies: an indirect comparison of randomised clinical trials in chronic low back pain. Eur Spine J. 2013;22(9): 1996-2009.

45. Qaseem A, Wilt TJ, McLean RM, Forciea MA. Noninvasive treatments for acute, subacute, and chronic low back pain: a clinical practice guideline from the American College of Physicians. Ann Intern Med. 2017;166(7):514-30. 
46. Perrot S, Maheu E, Javier RM, Eschalier A, Coutaux A, LeBars M, et al. Guidelines for the use of antidepressants in painful rheumatic conditions. Eur J Pain. 2006;10(3):185.

47. Perrot S, Javier R-M, Marty M, Le Jeunne C, Laroche F, CEDR FRS. Pain study section. Is there any evidence to support the use of anti-depressants in painful rheumatological conditions? Systematic review of pharmacological and clinical studies. Rheumatology. 2008;47(8):1117-23.

48. Patetsos E, Horjales-Araujo E. Treating chronic pain with SSRIs: what do we know? Pain Research and Management. 2016;2016:2020915.

49. Schnitzer TJ, Ferraro A, Hunsche E, Kong SX. A comprehensive review of clinical trials on the efficacy and safety of drugs for the treatment of low back pain. J Pain Symptom Manag. 2004;28(1):72-95.

50. Light RJ, Pillemer DB. Summing up: the science of reviewing research Harvard University press: Cambridge, MA, 1984, xiii+191 pp. Educ Res. 1986;15(8):16-7.

51. Begg CB, Mazumdar M. Operating characteristics of a rank correlation test for publication Bias. Biometrics. 1994;50(4):1088-101.

52. Egger M, Smith GD, Schneider M, Minder C. Bias in meta-analysis detected by a simple, graphical test. BMJ. 1997;315(7109):629-34.

53. Sterne JAC, Egger M, Smith GD. Investigating and dealing with publication and other biases in meta-analysis. BMJ. 2001;323(7304):101.

54. Maher C, Underwood M, Buchbinder R. Non-specific low back pain. Lancet. 2017;389(10070):736-47.

55. Baron R, Binder A, Attal N, Casale R, Dickenson A, Treede RD. Neuropathic low back pain in clinical practice. Eur J Pain. 2016;20(6):861-73.

56. Williamson OD, Sagman D, Bruins RH, Boulay LJ, Schacht A. Antidepressants in the treatment for chronic low Back pain: questioning the validity of Meta-analyses. Pain Pract. 2014;14(2):E33-41.

57. Tandon VR, Mahajan A, Singh K, Sharma A, Rai H. Antidepressants/ Antiepileptic drugs-Chronic Low Back pain. Pain. 2007;2:5

58. Maizels M, McCarberg B. Antidepressants and antiepileptic drugs for chronic non-cancer pain. Am Fam Physician. 2005;71(3):483-90

59. Dharmshaktu P, Tayal V, Kalra BS. Efficacy of antidepressants as analgesics: a review. J Clin Pharmacol. 2012;52(1):6-17.

60. Sardar K, Rashid M, Khandoker M, Khan A. Anticonvulsants and antidepressants in chronic pain management. J Recent Adv Pain. 2016:2(3):90-3

61. Pinto RZ, Verwoerd AJ, Koes BW. Which pain medications are effective for sciatica (radicular leg pain)? BMJ. 2017;359:j4248

62. Chou R, Côté P, Randhawa K, Torres P, Yu H, Nordin M, et al. The global spine care initiative: applying evidence-based guidelines on the noninvasive management of back and neck pain to low-and middle-income communities. Eur Spine J. 2018;27:1-10.

63. Koes BW, Backes D, Bindels PJ. Pharmacotherapy for chronic non-specific low back pain: current and future options. Expert Opin Pharmacother. 2018;19(6):537-45

64. Mika J, Zychowska M, Makuch W, Rojewska E, Przewlocka B. Neuronal and immunological basis of action of antidepressants in chronic pain-clinical and experimental studies. Pharmacol Rep. 2013;65(6):1611-21.

\section{Publisher's Note}

Springer Nature remains neutral with regard to jurisdictional claims in published maps and institutional affiliations.

Ready to submit your research? Choose BMC and benefit from:

- fast, convenient online submission

- thorough peer review by experienced researchers in your field

- rapid publication on acceptance

- support for research data, including large and complex data types

- gold Open Access which fosters wider collaboration and increased citations

- maximum visibility for your research: over $100 \mathrm{M}$ website views per year

At BMC, research is always in progress.

Learn more biomedcentral.com/submissions 